\title{
Preliminary results from breeding experiments with Finnsheep in Poland
}

\author{
S. JANKOWSKI, R. NIZNIKOWSKI and Z. TYSZKA
}

Warsaw Agricultural University, Institute of Animal Breeding, Przejazd 4, 05-Brwinow, Poland

\begin{abstract}
Polish Lowland (PL) ewes were mated to Finnsheep $\times$ East Friesian (EF) F1 rams to create a synthetic dam line (66), and to Polish Heath $\times$ EF F1 rams to create another synthetic dam line (77). Performance of both groups were recorded and compared to purebred PL (88). The numbers of animals in the composite lines were too small for statistical analyses and conclusive results. Contrary to expectations line 77 excelled line 88 in lambing rate by $3 \%$, while line 66 was inferior to it. In litter size, both composite lines slightly excelled line 88 . Line 66 excelled line 88 in lamb survival, while line 77 was a little inferior to it. In fleece weights, line 66 was equal with line 88 , but line 77 lagged $24 \%$ behind. Both of the composite lines excelled line 88 in daily gain by $10 \%$, being rather similar to each other.
\end{abstract}

Index words: Finnsheep, Polish Lowland, East Friesian, Polish Heath, synthetic, dam line, lambing rate, lamb survival, fleece, growth rate

\section{Introduction and experimental}

Very good results of commercial crossing of Polish Lowland (PL) (Corriedale type) ewes to Finnsheep $(\mathrm{F})$ rams encouraged us to make an attempt to create a synthetic dam line. PL ewes were mated to $\mathrm{F} \times$ East Friesian $(\mathrm{EF}) \mathrm{F} 1$ rams. The latter breed was introduced into the gene pool because of its high growth potential, milking ability and good quality of wool. In the years 1987-88, performance of the resulting progeny, called line 66 , was recorded. Still earlier we had started the creation of another dam line to which, instead of F, Polish native Wrzosowka ( $\mathrm{W}=$ Polish Heath) breed was introduced. The formula of this line, called line 77, was as follows: $50 \%$ of PL breed, $25 \%$ of $\mathrm{W}$ and $25 \%$ of EF. The performance of this line has also been recorded for several years. Both new lines were compared to purebred PL, called in this experiment line 88 and used as a control.

Because of the small numbers of animals, the results were calculated as simple means, weighted by the numbers of animals in different age classes in different years. Relative values were computed by using the same annual means of line 88 , since age class means of this line were not available. 
Table 1. Fecundity, prolificacy and lamb survival of ewes of two composite lines and of Polish Lowland in $1985-88$.

\begin{tabular}{|c|c|c|c|c|c|c|c|c|}
\hline \multirow[t]{2}{*}{ Line } & \multirow{2}{*}{$\begin{array}{l}\text { Age } \\
\text { of } \\
\text { ewes }\end{array}$} & \multirow{2}{*}{$\begin{array}{l}\text { No. of } \\
\text { ewe } \\
\text { years }\end{array}$} & \multicolumn{2}{|c|}{ Fecundity } & \multicolumn{2}{|c|}{ Prolificacy } & \multicolumn{2}{|c|}{ Lamb survival } \\
\hline & & & $\begin{array}{c}\mathrm{EL} / \mathrm{EM} \\
\%\end{array}$ & $\begin{array}{c}\text { Rel. } \\
\%\end{array}$ & $\begin{array}{c}\mathrm{LB} / \mathrm{EM} \\
\%\end{array}$ & $\underset{\%}{\text { Rel. }}$ & $\underset{\%}{\mathrm{LW} / \mathrm{LB}}$ & $\underset{\%}{\text { Rel. }}$ \\
\hline 66 & $2-3$ & 22 & 90.9 & 96.8 & 144.0 & 109.0 & 100.0 & 106.0 \\
\hline 77 & $2-4$ & 55 & 98.3 & 103.4 & 164.9 & 119.8 & 90.1 & 96.5 \\
\hline 88 (PL) & mix. & 520 & 95.5 & 100.0 & 137.8 & 100.0 & 93.4 & 100.0 \\
\hline
\end{tabular}

$\mathrm{EL}=$ ewes lambed; $\mathrm{EM}=$ No. ewes mated; $\mathrm{LB}=$ No. lambs born; $\mathrm{LW}=$ No. lambs weaned.

Table 2. Fleece weights of ewes of two composite lines and of Polish Lowland in 1986-88.

\begin{tabular}{lcccc}
\hline Line & $\begin{array}{c}\text { Age of } \\
\text { ewes }\end{array}$ & $\begin{array}{c}\text { No. of } \\
\text { ewe years }\end{array}$ & $\begin{array}{c}\text { Mean fleece } \\
\text { weight, kg (a) }\end{array}$ & $\begin{array}{c}\text { Relative to } \\
\text { line 88, \% (b) }\end{array}$ \\
\hline 66 & $2-3$ & 22 & 5.12 & 99.3 \\
77 & $2-4$ & 47 & 4.05 & 77.6 \\
$88(\mathrm{PL})$ & mixed & 400 & 5.12 & 100.0 \\
\hline
\end{tabular}

(a) weighted with numbers of ewes in different age classes in different years;

(b) comparisons made to corresponding years and relative values weighted with the numbers of ewes in different age classes;

Table 3. Average daily gains (ADG) of lambs of two composite lines and Polish Lowland from 70 to 185 days of age in 1987

\begin{tabular}{lccccccc}
\hline Line & \multicolumn{3}{c}{ Ram lambs } & & \multicolumn{3}{c}{ Ewe lambs } \\
\cline { 2 - 4 } \cline { 5 - 8 } & $\begin{array}{c}\text { No. } \\
\text { lambs }\end{array}$ & $\begin{array}{c}\text { ADG } \\
\mathrm{g}\end{array}$ & $\begin{array}{c}\text { Rel. } \\
\%\end{array}$ & & $\begin{array}{c}\text { No. } \\
\text { lambs }\end{array}$ & $\begin{array}{c}\text { ADG } \\
\mathrm{g}\end{array}$ & $\begin{array}{c}\text { Rel. } \\
\%\end{array}$ \\
\hline 66 & 11 & 121 & 110 & 13 & 102 & 113 \\
77 & 12 & 147 & 135 & & 14 & 96 & 107 \\
$88(\mathrm{PL})$ & 76 & 110 & 100 & 71 & 90 & 100 \\
\hline
\end{tabular}

\section{Results and conclusions}

The data recorded concerned: (1) reproduction, (2) fleece weight, and (3) lamb growth rate. The results are shown in tables 1,2 and 3 , respectively, from which the following preliminary conclusions can be made without statistical significances:

1. Surprisingly, line 66 with $25 \% \mathrm{~F}$ genes had the lowest fertility rate, while line 77 with $25 \% \mathrm{~W}$ showed the best result.

2. Line 66 was inferior to line 77 also in lit- ter size, but it excelled line 88 .

3. In lamb survival, line 66 showed the best mean, while line 77 had the lowest value.

4. Line 66 was very similar to line 88 in fleece weight, but line 77 gave a $24 \%$ lower value.

5. The composite lines 66 and 77 were equal in growth rate, exceeding that of line 88 by more than $10 \%$.

6. The results need to be confirmed in further experiments on more numerious material.

\section{References}

1. Niznikowskı, R., TYSZKA, Z. \& JANIKOWSKı, W., 1988. Meat, wool and milk utilization together with comparison of F1 coming from Finnsheep rams with F1

coming from other prolific breeds. J. Agric. Sci. Finl. 60: $534-537$. 